\title{
The effect of plant extracts as seed treatments to control bacterial leaf spot of tomato in Tanzania
}

\author{
Ernest R. Mbega $\cdot$ Carmen N. Mortensen · \\ Robert B. Mabagala $\cdot$ Ednar G. Wulff
}

Received: 3 December 2011/ Accepted: 6 March 2012/Published online: 5 May 2012

(c) The Author(s) 2012. This article is published with open access at Springerlink.com

\begin{abstract}
Bacterial leaf spot (BLS) caused by seed-borne xanthomonads is a serious disease of tomato (Solanum lycopersicum L.), causing significant losses in both yield and quality. To identify more effective control measures, we evaluated crude extracts from 84 plant species in in vitro and in planta assays for antibacterial activity against BLS of tomato. In the in vitro assays, $20.2 \%$ of the tested plant extracts totally inhibited growth of bacteria when seed washings from treated seeds were plated on nutrient agar medium. In the in planta assays, $17.8 \%$ of the tested plant extracts reduced BLS incidence by $100 \%$ in tomato seedlings. The most effective seed treatments were obtained with extracts from Aloe vera, Betula pendula, Coffea arabica, Glycyrrhiza uralensis, Juniperus communis, Ocimum basilicum, Quercus robur, Rheum palmatum, Rosmarinus officinalis, Ruta graveolens, Sinapis alba, Yucca schidigera and Salvia officinalis. Seed treatment of tomato with these extracts completely inhibited Xanthomonas perforans in both in vitro and in planta assays. Extracts from A. vera, C. arabica and $Y$. schidigera were tested three times using tomato seeds of cultivars Tanya, Cal-J and Moneymaker in Tanzania. Treatment of tomato seeds with these extracts had a positive effect on the number of normal seeds and had no effect on seedling
\end{abstract}

\footnotetext{
E. R. Mbega $(\bowtie) \cdot$ C. N. Mortensen · E. G. Wulff Department of Agriculture and Ecology, Faculty of Life Sciences, Danish Seed Health Centre for Developing Countries, University of Copenhagen, Copenhagen, Denmark

e-mail: mbegaernest@yahoo.co.uk

E. R. Mbega - R. B. Mabagala

Department of Crop Science and Production,

African Seed Health Centre, Sokoine University of Agriculture, P.O. Box 3005, Morogoro, Tanzania
}

vigor, height and weight. These results indicate that plant extracts from A. vera, $C$. arabica and $Y$. schidigera are potential candidates for seed treatment against seed-borne xanthomonads of tomato in Tanzania.

Keywords Plant extracts - Antibacterial activity · Xanthomonas perforans · Tomato - Seed treatment

\section{Introduction}

Bacterial leaf spot (BLS) incited by Xanthomonas euvesicatoria, X. vesicatoria, $X$. perforans and $X$. gardneri (Anonymous 2006; Jones et al. 2004) is a serious disease of tomato (Solanum lycopersicum L.) that occurs worldwide in regions with warm and humid climates (Jones et al. 2000; Stall et al. 1994; Tamir-Ariel et al. 2007). The BLS xanthomonads also affect pepper (Capsicum spp.), reducing both fruit yield and quality. Recently, X. campestris pv. raphani (Punina et al. 2009) and X. arboricola (Myung et al. 2010; E. R. Mbega et al., unpublished data) were also reported as pathogens of tomato. The BLS xanthomonads can survive in seeds, plant debris and volunteer plants (Kaaya et al. 2003). Seed infection by BLS pathogens of about $40.7 \%$ has been reported in Tanzania, causing yield losses up to $45 \%$ (Black et al. 2001; Kaaya et al. 2003).

Management of BLS is limited to foliar applications of copper-based compounds. However, presence of strains of BLS pathogens with a high degree of tolerance to copper (Carrillo-Fasio et al. 2001; Gitaitis et al. 1992; Gore and O'Garro 1999; Lee and Cho 1996; Martin et al. 2004; Scheck et al. 1996; Shenge et al. 2007) and the considerable number of Xanthomonas species and races causing BLS symptoms in tomato and pepper (Jones et al. 2004) have made the control of the disease difficult. 
Plants synthesize a number of compounds with antibiotic and antimicrobial properties (Amadioha 2003; Kumar and Parmar 1996; Opara and Wokocha 2008; Prakash and Rao 1997). Such compounds can therefore, be exploited as an alternative approach to manage or control BLS. Some of the known advantages of using pesticides of plant origin to control plant diseases include low mammalian toxicity, minimum health hazards and environmental pollution, and low risks of development of resistance by pathogens (Amadioha 2003; Kumar and Parmar 1996; Prakash and Rao 1997). Biopesticides may also be less expensive, easily available (because of their natural occurrence) and depending on the concentration, they may have no effects on seed viability, plant growth and food quality (Opara and Wokocha 2008).

In the present study, we applied crude extracts from a large number of plant species to tomato seeds to evaluate their potential to control BLS. The effect of the most promising extracts on seed germination and tomato seedling growth was also investigated.

\section{Materials and methods}

Seed samples

Tomato (S. lycopersicum L.) seeds of cultivars Cal-J, Tanya and Moneymaker, collected from tomato growers in Tanzania, were tested for infection as described by International Seed Federation (2007). Seed samples that were free of infection by Xanthomonas spp. were used in the experiments. One thousand seeds per cultivar were surface-disinfested in $70 \%$ ethanol for $1 \mathrm{~min}$, then in $1 \%$ sodium hypochlorite for $3 \mathrm{~min}$ and rinsed three times in sterile distilled water. The seeds were then transferred to Petri dishes containing sterile filter papers and allowed to air-dry overnight in a laminar flow chamber and stored at $4{ }^{\circ} \mathrm{C}$ until used.

Seed inoculation with bacterial suspensions

Surface-disinfested seeds of tomato cultivar Tanya were inoculated with $X$. perforans strain NCPPB 4321 based on its ability to cause severe BLS symptoms on various tomato cultivars, including those grown in Tanzania. Inoculum was prepared from 24-h-old bacterial cultures grown on nutrient agar (NA) medium (meat extract $3 \mathrm{~g}$, Bacto peptone $5 \mathrm{~g}$, Bacto agar $20 \mathrm{~g}$, distilled water $1000 \mathrm{~mL}$ ) at $28{ }^{\circ} \mathrm{C}$. Bacterial cultures were flooded with $10 \mathrm{~mL}$ of sterile distilled water and gently scraped with a flamed Drigalski spatula. The inoculum suspension was then homogenized using a vortex mixer and suspended in sterile distilled water to obtain a ca. $10^{8} \mathrm{CFU} / \mathrm{mL}$ $\left(\mathrm{OD}_{600}=0.01\right)$ (NanoDrop, Thermo Fisher Scientific,
Beverly, MA, USA). One thousand seeds of tomato were vacuum-infiltrated for $30 \mathrm{~min}$ with $10 \mathrm{~mL}$ of the bacterial suspension, and seeds were air-dried in the laminar air flow chamber at $4{ }^{\circ} \mathrm{C}$ until used.

\section{Seed treatment with plant extracts}

Plant for extractions were obtained from companies in Denmark and farmers in Tanzania as shown in Table 1. Two grams of plant material were suspended in $20 \mathrm{~mL}$ sterile distilled water in a $50 \mathrm{~mL}$ conical flask to obtain a $10 \%(\mathrm{w} / \mathrm{v})$ concentration. The conical flasks with the suspensions were briefly heated on a hot electric plate until boiling and cooled for $5 \mathrm{~min}$. The suspensions were filtered through sterile cheesecloth, and the extracts were autoclaved at $115{ }^{\circ} \mathrm{C}$ for $15 \mathrm{~min}$ and kept at $4{ }^{\circ} \mathrm{C}$ until used. Twenty tomato seeds pre-inoculated with $X$. perforans were treated with $1 \mathrm{~mL}$ of the $10 \%$ plant extract in an Eppendorf tube and placed on an agitation table at $100 \mathrm{rpm}$ overnight at $25{ }^{\circ} \mathrm{C}$. Untreated, seeds treated with copper sulphate $\left(200 \mu \mathrm{g} / \mathrm{mL} \mathrm{CuSO}_{4} \cdot 5 \mathrm{H}_{2} \mathrm{O}\right)$ or sterile distilled were included as controls. After overnight incubation, the treated seeds were blot-dried and allowed to air-dry for $1 \mathrm{~h}$ in the laminar air flow cabinet.

Evaluation of antibacterial activity of plant extracts in vitro

Washing samples $(100 \mu \mathrm{L})$ from treated seeds were collected using sterile pipettes and serially diluted to $10^{-2}$ with sterile distilled water in Eppendorf tubes. An aliquot of $100 \mu \mathrm{L}$ from each dilution was spread onto $0.6 \mathrm{~cm}$ thick NA medium in Petri dishes (diameter $8.5 \mathrm{~cm} \times$ depth $1.3 \mathrm{~cm}$ ) using a sterile glass rod. The plates were incubated at $28{ }^{\circ} \mathrm{C}$. A pure culture of $X$. perforans NCPPB 4321 was included as a control. Yellow colonies with morphology and color similar to those of $X$. perforans were counted after $96 \mathrm{~h}$. The identity of suspected colonies from each plate was confirmed by pathogenicity tests. The abaxial surfaces of four 14-day-old plants of tomato cultivar Tanya were sprayed to runoff with an inoculum suspension of $10^{8} \mathrm{CFU} / \mathrm{mL} \quad\left(\mathrm{OD}_{600}=0.01\right)$ prepared from 24-h-old bacterial cultures grown on NA at $28{ }^{\circ} \mathrm{C}$. The inoculated seedlings were covered with polyethylene bags and kept in the growth chamber for 14 days. Seedlings sprayed with sterile saline water (containing $0.85 \%$ of $\mathrm{NaCl}$ ) were used as a negative control, and seedlings sprayed with suspensions prepared from the $X$. perforans culture served as positive controls. The plants were examined for symptoms 14 days after inoculation and scored as negative when no obvious symptoms were observed. Leaves with watersoaked lesions that developed into dark brown spots were scored as positive for BLS disease. 
Table 1 Origin of plant extracts and control of bacterial leaf spot (BLS) of tomato caused by Xanthomonas perforans after seed treatment with extracts or control treatments

\begin{tabular}{|c|c|c|c|c|c|c|}
\hline Common name & Scientific name & Family & Part tested & Origin & $\mathrm{CFU} / \mathrm{mL}$ & $\operatorname{BLS}-\mathrm{RI}(\%)^{\mathrm{a}}$ \\
\hline Aloe & Aloe vera $\mathrm{L}$. & Aloaceae & Stem & $\mathrm{NN}, \mathrm{DK}$ & $0.0 \times 10^{0}$ & 100 \\
\hline Silver birch & Betula pendula Roth. & Betulaceae & Leaf & NDC, DK & $0.0 \times 10^{0}$ & 100 \\
\hline Coffee & Coffea arabica $\mathrm{L}$. & Rubiaceae & Seed $^{\mathrm{b}}$ & Tanzania & $0.0 \times 10^{0}$ & 100 \\
\hline Licorice & Glycyrrhiza uralensis L. & Fabaceae & Stem/leaf & NDC, DK & $0.0 \times 10^{0}$ & 100 \\
\hline Juniper & Juniperus communis L. & Cupressaceae & Stem & NDC, DK & $0.0 \times 10^{0}$ & 100 \\
\hline Basil & Ocimum basilicum $\mathrm{L}$. & Lamiaceae & Leaf & NDC, DK & $0.0 \times 10^{0}$ & 100 \\
\hline Oak & Quercus robur $\mathrm{L}$. & Fagaceae & Bark & $\mathrm{NN}, \mathrm{DK}$ & $0.0 \times 10^{0}$ & 100 \\
\hline Rhubarb & Rheum palmatum $\mathrm{L}$. & Polygonaceae & Stem & $\mathrm{NN}, \mathrm{DK}$ & $0.0 \times 10^{0}$ & 100 \\
\hline Rosemary & Rosmarinus officinalis L. & Lamiaceae & Stem & $\mathrm{NN}, \mathrm{DK}$ & $0.0 \times 10^{0}$ & 100 \\
\hline Rue & Ruta graveolens $\mathrm{L}$. & Rutaceae & Stem & NDC, DK & $0.0 \times 10^{0}$ & 100 \\
\hline White mustard & Sinapis alba $\mathrm{L}$. & Brassicaceae & Root & NDC, DK & $0.0 \times 10^{0}$ & 100 \\
\hline Mojave yucca & Yucca schidigera $\mathrm{L}$. & Agavaceae & Stem & NDC, DK & $0.0 \times 10^{0}$ & 100 \\
\hline Sage & Salvia officinalis L. & Lamiaceae & Stem & NDC, DK & $0.0 \times 10^{0}$ & 100 \\
\hline Nor-grape 80 & Vitis vinifera $\mathrm{L}$. & Vitaceae & Stem/leaf & NDC, DK & $0.0 \times 10^{0}$ & 94 \\
\hline Punica & Punica granatum $\mathrm{L}$. & Punicaceae & Stem & NDC, DK & $0.0 \times 10^{0}$ & 86.7 \\
\hline Olive & Olea europaea $\mathrm{L}$. & Oleaceae & Leaf & NDC, DK & $0.0 \times 10^{0}$ & 81.2 \\
\hline Clove & Caryophyllus aromaticus L. & Myrtaceae & Twig & NDC, DK & $0.0 \times 10^{0}$ & 75 \\
\hline White willow & Salix alba $\mathrm{L}$. & Salicaceae & Bark & NN, DK & $2.0 \times 10^{0}$ & 100 \\
\hline Grape vine & Vitis vinifera $\mathrm{L}$. & Vitaceae & Leaf & NN, DK & $1.0 \times 10^{0}$ & 79.8 \\
\hline Quinoa & Chenopodium quinoa Wild. & Chenopodiaceae & Stem & NN, DK & $1.8 \times 10^{3}$ & 75 \\
\hline Soapwort & Saponaria officinalis L. & Caryophyllaceae & Stem/leaf & NN, DK & $2.2 \times 10^{1}$ & 100 \\
\hline Ginkgo & Ginkgo biloba L. & Ginkgoaceae & Leaf & NDC, DK & $3.3 \times 10^{4}$ & 94 \\
\hline Daisy & Bellis perennis L. & Asteraceae & Flower & NDC, DK & $4.0 \times 10^{4}$ & 90.1 \\
\hline Inula & Inula helenium $\mathrm{L}$. & Asteraceae & Stem & NDC, DK & $1.0 \times 10^{1}$ & 86.7 \\
\hline Rosemary & Rosmarinus officinalis L. & Lamiaceae & Leaf & NN, DK & $2.5 \times 10^{3}$ & 81.6 \\
\hline Tea & Camellia sinensis L. & Theaceae & Leaf & NDC, DK & $1.0 \times 10^{1}$ & 81.2 \\
\hline Bilberry & Vaccinium myrtillus L. & Vacciniaceae & Leaf & NN, DK & $1.0 \times 10^{1}$ & 81.2 \\
\hline Celery & Apium graveolens $\mathrm{L}$. & Apiaceae & Root & NDC, DK & $1.0 \times 10^{1}$ & 80 \\
\hline Ginseng & Panax ginseng C.A. Meyer. & Araliaceae & Stem/leaf & NDC, DK & $1.0 \times 10^{1}$ & 80 \\
\hline Burnet-saxifrage & Pimpinella saxifraga ssp. nigra (Mill) & Apiaceae & Stem & NN, DK & $1.0 \times 10^{6}$ & 80 \\
\hline Thyme & Thymus vulgaris L. & Lamiaceae & Leaf/stem & NDC, DK & $3.9 \times 10^{3}$ & 80 \\
\hline Maypop & Passiflora incarnata $\mathrm{L}$. & Passifloraceae & Flower & NN, DK & $6.0 \times 10^{4}$ & 79.8 \\
\hline Red pepper & Capsicum frutescens $\mathrm{L}$. & Solanaceae & Fruit & NN, DK & $1.8 \times 10^{5}$ & 73.4 \\
\hline Chamomile & Matricaria chamomilla L. & Asteraceae & Flower & $\mathrm{NN}, \mathrm{DK}$ & $2.0 \times 10^{1}$ & 73.3 \\
\hline Neem & Azadirachta indica $\mathrm{L}$. & Meliaceae & Seed & Tanzania & $7.0 \times 10^{2}$ & 68.7 \\
\hline Quinine & Cinchona pubescens Vahl. & Rubiaceae & Bark & NDC, DK & $9.0 \times 10^{1}$ & 66.7 \\
\hline High mallow & Malva sylvestris $\mathrm{L}$. & Malvaceae & Leaf & $\mathrm{NN}, \mathrm{DK}$ & $9.8 \times 10^{3}$ & 66.6 \\
\hline Cowslip & Primula veris $\mathrm{L}$. & Primulaceae & Stem & $\mathrm{NN}, \mathrm{DK}$ & $6.0 \times 10^{1}$ & 60 \\
\hline Sisal & Agave sisalana Perrine. & Agavaceae & Root & Tanzania & $>1.0 \times 10^{7}$ & 59.9 \\
\hline Agapanthus & Agapanthus sp. & Alliaceae & Leaf & NDC, DK & $1.9 \times 10^{5}$ & 53.2 \\
\hline Sisal & Agave sisalana Perrine. & Agavaceae & Leaf & Tanzania & $2.8 \times 10^{5}$ & 53.2 \\
\hline Couch grass & Agropyron repens (L.) Beauv. & Poaceae & Stem & NDC, DK & $1.1 \times 10^{3}$ & 53.1 \\
\hline Elm & Ulmus campestris $\mathrm{L}$. & Ulmaceae & Bark & $\mathrm{NN}, \mathrm{DK}$ & $5.5 \times 10^{2}$ & 49.5 \\
\hline Sisal & Agave sisalana Perrine. & Agavaceae & Stem & Tanzania & $1.9 \times 10^{5}$ & 46.8 \\
\hline Horsetail & Equisetum arvense $\mathrm{L}$. & Equisateaceae & Leaf & $\mathrm{ND}, \mathrm{DK}$ & $1.6 \times 10^{5}$ & 40 \\
\hline Black poplar & Populus nigra L. & Salicaceae & Twig & NN, DK & $6.0 \times 10^{0}$ & 40 \\
\hline Elderberry & Sambucus nigra $\mathrm{L}$. & Caprifoliaceae & Leaf & ND, DK & $6.0 \times 10^{0}$ & 40 \\
\hline Turmeric & Curcuma longa $\mathrm{L}$. & Zingiberaceae & Stem & $\mathrm{ND}, \mathrm{DK}$ & $>1.0 \times 10^{7}$ & 40 \\
\hline
\end{tabular}


Table 1 continued

\begin{tabular}{|c|c|c|c|c|c|c|}
\hline Common name & Scientific name & Family & Part tested & Origin & $\mathrm{CFU} / \mathrm{mL}$ & $\operatorname{BLS}-R I(\%)^{\mathrm{a}}$ \\
\hline Adam's needle & Yucca filamentosa $\mathrm{L}$. & Agavaceae & Stem & $\mathrm{NN}, \mathrm{DK}$ & $2.4 \times 10^{4}$ & 37.5 \\
\hline Onion & Allium cepa $\mathrm{L}$. & Liliaceae & Bud & $\mathrm{ND}, \mathrm{DK}$ & $2.0 \times 10^{6}$ & 33.5 \\
\hline Eucalyptus & Eucalyptus globulus L. & Myrtaceae & Leaf & Tanzania & $3.7 \times 10^{3}$ & 33.5 \\
\hline Avocado & Persea americana $\mathrm{L}$. & Lauraceae & Fruit peels & Tanzania & $>1.0 \times 10^{7}$ & 33.5 \\
\hline Buckthorn & Frangula alnus Mill. & Rhamnaceae & Bark & $\mathrm{ND}, \mathrm{DK}$ & $2.0 \times 10^{1}$ & 29.9 \\
\hline Plantain & Plantago major L. & Plantaginaceae & Leaf & $\mathrm{ND}, \mathrm{DK}$ & $6.0 \times 10^{5}$ & 29.9 \\
\hline Southernwood & Artemisia abrotanum L. & Asteraceae & Leaves & ND, DK & $5.8 \times 10^{6}$ & 26.8 \\
\hline Lemongrass & Cymbopogon citratus L. & Poaceae & Leaves & ND, DK & $9.8 \times 10^{5}$ & 26.8 \\
\hline Eucalyptus & Eucalyptus globulus L. & Myrtaceae & Seeds & Tanzania & $>1.0 \times 10^{7}$ & 26.8 \\
\hline White clover & Trifolium repens $\mathrm{L}$. & Fabaceae & Flower & $\mathrm{NN}, \mathrm{DK}$ & $2.6 \times 10^{5}$ & 26.8 \\
\hline Couch grass & Agropyron repens $\mathrm{L}$. & Poaceae & Leaf & $\mathrm{ND}, \mathrm{DK}$ & $1.9 \times 10^{5}$ & 26.7 \\
\hline Silver birch & Betula pendula Roth. & Betulaceae & Bark & $\mathrm{ND}, \mathrm{DK}$ & $5.0 \times 10^{3}$ & 26.7 \\
\hline Scots pine & Pinus sylvestris $\mathrm{L}$. & Pinaceae & Leaf & $\mathrm{ND}, \mathrm{DK}$ & $6.0 \times 10^{3}$ & 26.7 \\
\hline Red clover & Trifolium pratense $\mathrm{L}$. & Fabaceae & Flower & NN, DK & $6.8 \times 10^{3}$ & 26.7 \\
\hline Ginger & Zingiber officinale Rosc. & Zingiberaceae & Bud & NN, DK & $7.0 \times 10^{2}$ & 26.7 \\
\hline Yucca & Үисса sp. & Agavaceae & Stem/leaf & NN, DK & $2.6 \times 10^{3}$ & 25 \\
\hline Adam's needle & Yucca filamentosa $\mathrm{L}$. & Agavaceae & Leaf & NN, DK & $2.4 \times 10^{5}$ & 25 \\
\hline Oak & Quercus robur $\mathrm{L}$. & Fagaceae & Leaf & NN, DK & $7.0 \times 10^{1}$ & 18.7 \\
\hline Soapbark & Quillaja saponaria Molina. & Quillajaceae & Bark & NN, DK & $2.6 \times 10^{3}$ & 18.7 \\
\hline Chicory & Cichorium intybus L. & Asteraceae & Stem & $\mathrm{ND}, \mathrm{DK}$ & $1.0 \times 10^{5}$ & 13.5 \\
\hline Water mint & Mentha aquatica $\mathrm{L}$. & Lamiaceae & Leaf & $\mathrm{ND}, \mathrm{DK}$ & $4.0 \times 10^{5}$ & 13.5 \\
\hline Irish moss & Chondrus crispus L. & Gigartinaceae & Leaf & $\mathrm{ND}, \mathrm{DK}$ & $3.5 \times 10^{5}$ & 13.3 \\
\hline Tansy & Tanacetum vulgare $\mathrm{L}$. & Asteraceae & Stem/leaf & $\mathrm{ND}, \mathrm{DK}$ & $1.3 \times 10^{4}$ & 6.2 \\
\hline Neem & Azadirachta indica L. & Meliaceae & Leaf & Tanzania & $5.0 \times 10^{5}$ & 0 \\
\hline Bladderwrack & Fucus vesiculosus $\mathrm{L}$. & Fucaceae & Flower & $\mathrm{NN}, \mathrm{DK}$ & $6.9 \times 10^{4}$ & 0 \\
\hline Coral plant & Jatropha sp. & Euphorbiaceae & Seed & Tanzania & $2.2 \times 10^{5}$ & 0 \\
\hline Coral plant & Jatropha sp. & Euphorbiaceae & Leaf & Tanzania & $1.2 \times 10^{5}$ & 0 \\
\hline Lantana & Lantana camara $\mathrm{L}$. & Verbenaceae & Leaf & Tanzania & $5.0 \times 10^{4}$ & 0 \\
\hline Spiny restharrow & Ononis spinosa L. & Fabaceae & Leaf & $\mathrm{ND}, \mathrm{DK}$ & $6.0 \times 10^{5}$ & 0 \\
\hline Silverweed & Pontentilla anserine $\mathrm{L}$. & Rosaceae & Leaf & $\mathrm{ND}, \mathrm{DK}$ & $9.6 \times 10^{3}$ & 0 \\
\hline Quassia & Quassia sp. & Simaroubaceae & Bark & NN, DK & $1.3 \times 10^{5}$ & 0 \\
\hline Nettle & Urtica sp. & Urticaceae & Leaf & $\mathrm{ND}, \mathrm{DK}$ & $1.4 \times 10^{5}$ & 0 \\
\hline Mistletoe & Viscum album L. & Loranthaceae & Leaf/stem & $\mathrm{ND}, \mathrm{DK}$ & $4.6 \times 10^{5}$ & 0 \\
\hline Cardamon & Ellettaria cardamomum L. & Zingiberaceae & & $\mathrm{ND}, \mathrm{DK}$ & $>1.0 \times 10^{7}$ & -10 \\
\hline Alfalfa & Medicago sativa ssp. sativa $\mathrm{L}$. & Fabaceae & Seed & $\mathrm{ND}, \mathrm{DK}$ & $>1.0 \times 10^{7}$ & -10 \\
\hline Fenugreek & Trigonella foenum-graecum $\mathrm{L}$. & Fabaceae & Seed & ND, DK & $1.3 \times 10^{6}$ & -20 \\
\hline \multicolumn{7}{|l|}{ Controls } \\
\hline Sterile distilled water & - & - & - & - & $>1.0 \times 10^{7}$ & 0 \\
\hline Copper sulphate & - & - & - & - & $0.0 \times 10^{0}$ & 100 \\
\hline Untreated seed & - & - & - & - & 0 & 0 \\
\hline
\end{tabular}

- not applicable, $N N, D K$ Nor-Natur, Denmark, $N D, D K$ Natur Drogeriet, Denmark

${ }^{a}$ Bacterial leaf spot reduction index (BLS-RI) was calculated as $(\mathrm{C}-T) / C \times 100 \%$, where $C$ is the incidence of BLS in tomato seedlings treated with sterile distilled water (negative control) and $T$ is the incidence of BLS of tomato seedlings treated with plant extract

b Processed coffee (Africafe ${ }^{\circledR}$ ) from Afri Tea and Coffee Blenders (1993) Ltd., Dar es Salaam, Tanzania 
Evaluation of antibacterial activity

of plant extracts in planta

To evaluate the effect of the plant extracts on the control of $X$. perforans in seedling assays, 16 tomato seeds treated with plant extracts as previously described were sown in pots $(8 \mathrm{~cm}$ diameter $)$ containing a $1: 3$ ratio of sterile sand and peat soil (Pindstrup substrate No. 2, Pindstrup Mosebrug A/S, Ryomgaard, Denmark) and kept in growth chamber at $28{ }^{\circ} \mathrm{C}$ under high relative humidity (>85\%). Twenty-one days after sowing, BLS incidence was assessed by calculating the percentage of seedlings with leaf spot symptoms in the total number of emerged seedlings. The efficacy of plant extract treatments in the control of BLS in tomato seedlings was calculated as the BLS reduction index $(\mathrm{BLS}-\mathrm{RI})=(C-T) / C \times 100 \%$, where $C$ is the incidence of BLS in tomato seedlings raised from seeds treated with sterile distilled water (negative control) and $T$ is the incidence of BLS in tomato seedlings from infected seeds treated with a given plant extract. In addition to the BLS incidence and reduction index, the height, mass and width of seedlings were also evaluated for the bestperforming plant extracts. The height of the seedlings was determined by measuring the aerial part of the seedlings from the soil surface to the node of the terminal developing leaf. Fresh mass of the aerial plant part was determined using tomato seedlings cut at the base of the stem by a pair of scissors, and the seedling mass was weighed. To determine the width of the seedlings, we placed a digital caliper at a right angle to the seedlings and recorded the reading at the widest point of the stem. The measurements were repeated in three independent experiments. Plant extracts with the best ability to reduce BLS in tomato during the initial screening tests were determined by comparing the data obtained with Student-Newman-Kuels (SNK) test using SAS version 9.1 software (SAS Institute, Cary, NC, USA). The choice of plant extracts used for screenhouse evaluations in Tanzania was based on four criteria: (1) effectiveness in reducing BLS, (2) most normal seedlings in germination tests, (3) highest vigor index in seedling assays and (4) no phytotoxicity.

Effect of plant extracts on seed germination and seedling growth

The effect of selected plant extracts on seed germination, seedling vigor and mass was evaluated in Xanthomonasfree tomato seeds treated with plant extracts as previously described. Seed germination tests were conducted using 400 tomato seeds per treatment. The standard International Seed Testing Association top of paper method (ISTA 2005) was used. The seeds were plated uniformly (50 seeds per replicate) onto three layers of moist blotter paper in a plastic container kept at $27 \pm 2{ }^{\circ} \mathrm{C}$ and $\mathrm{RH}>85 \%$ for 14 days. Normal and abnormal seedlings and dead seeds were counted for the germination tests. The same seedlings were used to determine vigor and dry mass. The vigor test involved measurements of root and shoot lengths of seedlings and the percentage seed (normal seedlings) germination. The seedling vigor index $(\mathrm{Vi})$ was calculated as $\mathrm{Vi}=($ mean root length + mean shoot length $) \times($ percentage germination) (Abdul-Baki and Anderson 1973). To determine the dry mass, we wrapped seedlings from each treatment in the germination tests in aluminium foil and dried them in an oven at $103{ }^{\circ} \mathrm{C}$ for $24 \mathrm{~h}$. The dried seedlings were then allowed to cool to room temperature and weighed.

Evaluation of plant extracts for production of healthy tomato transplants in the screenhouse

Tomato seeds of cultivars Tanya, Cal-J and Moneymaker, collected from tomato growers in Tanzania and free of BLScausing xanthomonads, were inoculated with $X$. perforans and treated with plant extracts as previously described. One hundred seeds per cultivar per treatment were sown in polyethylene plastic trays $(56.5 \times 26.5 \times 6 \mathrm{~cm})$ containing a mixture of forest soil, rice husks and farmyard manure (3:1:1). The trays were kept in the screenhouse at $25-33{ }^{\circ} \mathrm{C}$ and $\mathrm{RH}>85 \%$. Seven days after sowing, 40 seedlings per treatment of each cultivar (10 seedlings per replicate in four replications) were randomly selected and transferred to polyethylene sleeves $(6.5 \times 9.0 \mathrm{~cm})$ containing the same growth substrate as previously described. The sleeves with the seedlings were placed on the screenhouse benches at the same temperature and RH. BLS incidence and severity in the tomato seedlings were assessed 21 days after sowing. Disease severity was determined based on the Horsfall and Barrett (1945) scale with minor modifications (Shenge 2006), where $1=$ no disease, $2=>0-3 \%$ of leaves with BLS symptoms, $3=>3-12 \%$ of leaves with BLS symptoms, $4=>12-25 \%$ of leaves with BLS symptoms, $5=>25-50 \%$ of leaves with BLS symptoms and $6=>50 \%$ of leaves with BLS symptoms. In addition to disease incidence and severity, the height and mass of seedlings were also evaluated as already described. The experiment was repeated three times from March to September 2010.

\section{Data analysis}

In the in vitro assays, the average of the total number of colony forming units of $X$. perforans on NA was calculated based on three replications. Data for BLS incidence, severity, seed germination, seedling vigor, plant dry and fresh mass and plant height were analyzed using Proc 
GLM, and mean separation tests were calculated with the Student-Newman-Kuels (SNK) using SAS version 9.1 software (SAS Institute).

\section{Results}

Results for preliminary screening of the effectiveness of plant extracts on $X$. perforans indicated that 17 of 84 tested plant extracts $(20.2 \%)$ were able to totally reduce the pathogen in in vitro assays (Table 1). The extracts were from Aloe vera, Betula pendula, processed Coffea arabica, Glycyrrhiza uralensis, Juniperus communis, Ocimum basilicum, Quercus robur, Rheum palmatum, Rosmarinus officinalis, Ruta graveolens, Sinapsis alba, Yucca schidigera, Salvia officinalis, Vitis vinifera, Punica granatum, Olea europea and Caryophillus aromaticus. The effect of these plant extracts on $X$. perforans was similar to that obtained when seeds were treated with copper sulphate (Table 1).

In the in planta assays, 15 of 84 plant extracts $(17.8 \%)$ completely inhibited symptoms of BLS in tomato seedlings. Such plant extracts were from A. vera, B. pendula, C. arabica, G. uralensis, J. communis, O. basilicum, $Q$. robur, $R$. palmatum, $R$. officinalis, R. graveolens, S. alba, Y. schidigera and S. officinallis (Table 1). Only 13 of 84 extracts (corresponding to $15.5 \%$ ) of the assayed plant extracts controlled BLS in both in vitro and in planta assays. These extracts were from A. vera, B. pendula, C. arabica, G. uralensis, J. communis, O. basilicum,
Q. robur, R. palmatum, R. officinalis, R. graveolens, S. alba, Y. schidigera and S. officinalis and were selected for further experiments.

The results obtained from evaluation of the best-performing plant extracts are shown in Table 2. The 13 selected plant extracts all significantly reduced $(P<0.001)$ the incidence of BLS in tomato seedlings without significantly affecting the growth of tomato seedlings. Seed treatment with plant extracts from A. vera, C. arabica, G. uralensis and $Y$. schidigera totally reduced $(P<0.001)$ the incidence of BLS in tomato (Table 2). The efficacy of these plant extracts to inhibit the growth of $X$. perforans was similar to the effects obtained when seeds were treated with copper sulphate (bactericide) control and untreated (disease free) seed control.

The results also showed that, treatment of tomato seeds with the best-performing plant extracts did not negatively affect the growth of tomato seedlings compared to the treatment with copper sulphate and untreated, disease-free seeds. In contrast, seed treatment with sterile distilled water (negative control) resulted in seedlings with significantly lower $(P<0.001)$ fresh mass $(0.31 \mathrm{~g})$ and width $(1.45 \mathrm{~mm})$ compared to the other seed treatments (Table 2).

The effects of tomato seed treatment with $10 \%$ aqueous plant extracts from A. vera, C. arabica, G. uralensis and $Y$. schidigera on seed germination, seedling vigor and dry mass is summarised in Table 3. Treatment of tomato seeds with extracts from A. vera, C. arabica and Y. schidigera significantly increased $(P<0.05)$ the number of normal
Table 2 Effect of seed treatment with selected plant extracts on incidence of bacterial leaf spot caused by Xanthomonas perforans and on growth of tomato seedlings of cultivar Tanya

\footnotetext{
*** Significant at $P=0.01$

${ }^{\text {a }}$ BLS incidence $=$ percentage of seedlings with bacterial leaf spot symptoms. Mean followed by same letters in a column are not significantly different based on the SNK test at $P=0.05$. Each value is a mean of 48 seedlings
}

\begin{tabular}{lllll}
\hline Treatment & Incidence $(\%)^{\mathrm{a}}$ & Height $(\mathrm{cm})$ & Mass $(\mathrm{g})$ & Width $(\mathrm{mm})$ \\
\hline Control & & & & \\
Sterile distilled water & $83.30 \mathrm{a}$ & $13.50 \mathrm{~b}$ & $0.31 \mathrm{~d}$ & $1.45 \mathrm{~d}$ \\
Copper sulphate & $0.00 \mathrm{e}$ & $16.13 \mathrm{a}$ & $0.85 \mathrm{abc}$ & $1.81 \mathrm{abc}$ \\
Untreated seed & $0.00 \mathrm{e}$ & $15.98 \mathrm{a}$ & $0.75 \mathrm{bc}$ & $1.78 \mathrm{c}$ \\
Plant extract & & & & \\
Aloe vera & $0.00 \mathrm{e}$ & $17.28 \mathrm{a}$ & $0.96 \mathrm{abc}$ & $2.05 \mathrm{ab}$ \\
Betula pendula & $18.80 \mathrm{~b}$ & $16.90 \mathrm{a}$ & $0.83 \mathrm{abc}$ & $2.00 \mathrm{abc}$ \\
Coffea arabica & $0.00 \mathrm{e}$ & $17.13 \mathrm{a}$ & $0.98 \mathrm{ab}$ & $2.04 \mathrm{ab}$ \\
Glycyrrhiza uralensis & $0.00 \mathrm{e}$ & $17.23 \mathrm{a}$ & $0.96 \mathrm{abc}$ & $2.06 \mathrm{ab}$ \\
Juniperus communis & $6.30 \mathrm{~d}$ & $16.11 \mathrm{a}$ & $0.72 \mathrm{c}$ & $1.97 \mathrm{abc}$ \\
Ocimum basilicum & $18.80 \mathrm{~b}$ & $16.84 \mathrm{a}$ & $0.78 \mathrm{abc}$ & $1.93 \mathrm{abc}$ \\
Quercus robur & $18.80 \mathrm{~b}$ & $16.69 \mathrm{a}$ & $0.82 \mathrm{abc}$ & $1.97 \mathrm{abc}$ \\
Rheum palmatum & $18.80 \mathrm{~b}$ & $16.50 \mathrm{a}$ & $0.82 \mathrm{abc}$ & $2.04 \mathrm{ab}$ \\
Rosmarinus officinalis & $18.80 \mathrm{~b}$ & $16.06 \mathrm{a}$ & $0.78 \mathrm{abc}$ & $1.98 \mathrm{abc}$ \\
Ruta graveolens & $18.80 \mathrm{~b}$ & $16.16 \mathrm{a}$ & $0.49 \mathrm{ab}$ & $1.82 \mathrm{abc}$ \\
Salvia officinalis & $12.50 \mathrm{c}$ & $16.56 \mathrm{a}$ & $0.82 \mathrm{abc}$ & $2.04 \mathrm{ab}$ \\
Sinapis alba & $12.50 \mathrm{c}$ & $16.13 \mathrm{a}$ & $0.74 \mathrm{c}$ & $1.90 \mathrm{abc}$ \\
Yucca schidigera & $0.00 \mathrm{e}$ & $17.24 \mathrm{a}$ & $1.00 \mathrm{a}$ & $2.13 \mathrm{a}$ \\
Mean & 12.31 & 16.47 & 0.81 & 1.95 \\
F test & $* * *$ & $* * *$ & $* * *$ & $* * *$ \\
\hline
\end{tabular}


Table 3 The effect of treatment with selected plant extracts from Aloe vera, Coffea arabica, Glycyrrhiza uralensis and Yucca schidigera on tomato seed germination, seedling vigor and dry weight of tomato plants

\begin{tabular}{|c|c|c|c|c|c|}
\hline \multirow[t]{2}{*}{ Treatment } & \multicolumn{3}{|c|}{ Seed germination ${ }^{\mathrm{a}}$} & \multirow[t]{2}{*}{ Vigor index $(\%)^{\mathrm{b}}$} & \multirow[t]{2}{*}{ Dry mass $(\mathrm{g})$} \\
\hline & NS (\%) & ABS $(\%)$ & DS $(\%)$ & & \\
\hline \multicolumn{6}{|l|}{ Control } \\
\hline Sterile distilled water & $90.50 \mathrm{~b}$ & $3.00 \mathrm{a}$ & $6.50 \mathrm{a}$ & $702.51 b$ & $0.16 \mathrm{a}$ \\
\hline Copper sulphate & $92.80 \mathrm{ab}$ & $2.30 \mathrm{a}$ & $5.00 \mathrm{ab}$ & $707.60 \mathrm{~b}$ & $0.14 \mathrm{a}$ \\
\hline Untreated seed & $92.00 \mathrm{ab}$ & $3.50 \mathrm{a}$ & $4.50 \mathrm{ab}$ & $718.06 \mathrm{~b}$ & $0.16 \mathrm{a}$ \\
\hline \multicolumn{6}{|l|}{ Plant extract } \\
\hline A. vera & $94.80 \mathrm{a}$ & $1.80 \mathrm{a}$ & $3.50 \mathrm{ab}$ & 749.39ab & $0.14 \mathrm{a}$ \\
\hline C. arabica & $95.50 \mathrm{a}$ & $2.50 \mathrm{a}$ & $2.00 \mathrm{~b}$ & $784.77 \mathrm{a}$ & $0.14 \mathrm{a}$ \\
\hline G. uralensis & $92.80 \mathrm{ab}$ & $2.80 \mathrm{a}$ & $4.50 \mathrm{ab}$ & $714.33 b$ & $0.16 \mathrm{a}$ \\
\hline Y. schidigera & $94.30 \mathrm{a}$ & $2.00 \mathrm{a}$ & $3.80 \mathrm{ab}$ & $741.91 \mathrm{ab}$ & $0.14 \mathrm{a}$ \\
\hline Mean & 93.20 & 2.50 & 4.30 & 731.22 & 0.14 \\
\hline$F$ test & $* *$ & ns & $* *$ & $* *$ & ns \\
\hline
\end{tabular}

$n s$ not significant

** Significant at $P=0.05$

a Seed germination states: $N S$ normal seedlings, $A B S$ abnormal seedlings, $D S$ dead seed. Each value is the percentage from 400 seeds test

b Seedling vigor index (Vi) was calculated as $\mathrm{Vi}=$ (mean root length + mean shoot length) $\times$ (percentage germination) $($ Abdul-Baki and Anderson 1973); means followed by the same letters in a column are not significantly different based on the SNK test at $P=0.05$

seedlings compared to seeds treated with sterile distilled water (negative control). The number of normal seedlings obtained from seeds treated with these extracts was not significantly different from those obtained from copper sulphate (positive control) and untreated tomato seeds (Table 3). The number of normal seedlings obtained with seeds treated with plant extracts of $G$. uralensis was not significantly different $(P<0.05)$ from seed treatments using plant extracts from $A$. vera, $C$. arabica and $Y$. schidigera, (positive and negative controls, respectively). The number of abnormal seedlings was not significantly different $(P<0.05)$ between different seed treatments (Table 3 ). When the number of dead tomato seeds was compared between seed treatments, there was no significant difference $(P<0.05)$ between most treatments, except for tomato seeds treated with $C$. arabica (Table 3), which significantly increased $(P<0.05)$ tomato seedling vigor. The treatment of tomato seeds with extracts from $A$. vera and $Y$. schidigera were not significantly different $(P<0.05)$ from seeds treated with $C$. arabica, positive and negative controls (Table 3 ).

Seed treatment of tomato with plant extracts from A. vera, C. arabica and $Y$. schidigera significantly reduced the incidence and severity of BLS $(P<0.001)$ in all three experiments. Such effects were similar to those obtained for seedlings grown from tomato seeds treated with copper sulphate and untreated seeds (disease-free) control (Table 4). In all three experiments, the incidence and severity of BLS disease were significantly higher $(P<0.001)$ in tomato transplants of cultivars Tanya, Cal-J and Moneymaker treated with sterile distilled water (negative control) compared to the other treatments (Table 4).

\section{Discussion}

Tomato seeds were treated with aqueous extracts from 84 different plant materials to assess control of seed-borne infection of BLS of tomato caused by $X$. perforans. In the in vitro assays, $20.2 \%$ of the tested plant extracts totally inhibited growth of $X$. perforans when seed washings from treated seeds were plated on NA. In the in planta experiments, notably $17.8 \%$ of the tested plant extracts reduced BLS incidence by $100 \%$ in tomato seedlings (Table 1). The most effective seed treatments, giving $100 \%$ control in vitro and in planta, were obtained when tomato seeds were treated with plant extracts from A. vera, B. pendula, C. arabica, G. uralensis, J. communis, O. basilicum, $Q$. robur, R. palmatum, R. officinalis, R. graveolens, S. alba, Y. schidigera and S. officinalis (Table 1).

From the in planta evaluation of the 13 best performing plant extracts (Table 2), extracts from A. vera, C. arabica, G. uralensis and $Y$. schidigera were the most effective and promising for control of BLS of tomato when applied as seed treatment (Table 2). Such results indicate that these plant extracts have bactericidal properties and can be used for tomato seed treatment to control xanthomonads associated with BLS. Many reports are available on the antibacterial properties of these plants. The antibacterial activity of A. vera against Shigella flexneri and Streptococcus 
Table 4 The effect of selected plant extracts from Aloe vera, Coffea arabica and Yucca schidigera applied as seed treatment on incidence and severity of bacterial leaf spot (BLS) caused by Xanthomonas perforans on three tomato cultivars under screenhouse conditions in Morogoro, Tanzania

\begin{tabular}{|c|c|c|c|c|c|c|c|}
\hline \multirow[t]{2}{*}{ Cultivar } & \multirow[t]{2}{*}{ Treatment } & \multicolumn{2}{|l|}{ Experiment 1} & \multicolumn{2}{|l|}{ Experiment 2} & \multicolumn{2}{|l|}{ Experiment 3} \\
\hline & & Incidence $(\%)^{\mathrm{a}}$ & Severity index ${ }^{b}$ & Incidence $(\%)$ & Severity index & Incidence $(\%)$ & Severity index \\
\hline \multirow[t]{10}{*}{ Tanya } & Control & & & & & & \\
\hline & Sterile distilled water & $45.00 \mathrm{a}$ & $2.15 \mathrm{a}$ & $82.50 \mathrm{a}$ & $2.56 \mathrm{a}$ & 65.00 & $2.18 \mathrm{a}$ \\
\hline & Copper sulphate & $10.00 \mathrm{~b}$ & $1.10 \mathrm{~b}$ & $0.00 \mathrm{~b}$ & $1.00 \mathrm{~b}$ & $2.50 \mathrm{~b}$ & $1.02 \mathrm{~b}$ \\
\hline & Untreated seed & $0.00 \mathrm{~b}$ & $1.00 \mathrm{~b}$ & $0.00 \mathrm{~b}$ & $1.00 \mathrm{~b}$ & $0.00 \mathrm{~b}$ & $1.00 \mathrm{~b}$ \\
\hline & Extract & & & & & & \\
\hline & A. vera & $2.50 \mathrm{~b}$ & $1.02 \mathrm{~b}$ & $0.00 \mathrm{~b}$ & $1.00 \mathrm{~b}$ & $0.00 \mathrm{~b}$ & $1.00 \mathrm{~b}$ \\
\hline & C. arabica & $0.00 \mathrm{~b}$ & $1.00 \mathrm{~b}$ & $0.00 \mathrm{~b}$ & $1.00 \mathrm{~b}$ & $0.00 \mathrm{~b}$ & $1.00 \mathrm{~b}$ \\
\hline & Y. schidigera & $0.00 \mathrm{~b}$ & $1.00 \mathrm{~b}$ & $0.00 \mathrm{~b}$ & $1.00 \mathrm{~b}$ & $0.00 \mathrm{~b}$ & $1.00 \mathrm{~b}$ \\
\hline & Mean & 9.58 & 1.21 & 13.75 & 1.26 & 11.25 & 1.20 \\
\hline & $F$ test & $* * *$ & $* * *$ & $* * *$ & $* * *$ & **** & $* * *$ \\
\hline \multirow[t]{10}{*}{ Cal-J } & Control & & & & & & \\
\hline & Sterile distilled water & $70.00 \mathrm{a}$ & $2.18 \mathrm{a}$ & $80.00 \mathrm{a}$ & $2.55 \mathrm{a}$ & $60.00 \mathrm{a}$ & $1.65 \mathrm{a}$ \\
\hline & Copper sulphate & $0.00 \mathrm{~b}$ & $1.00 \mathrm{~b}$ & $0.00 \mathrm{~b}$ & $1.00 \mathrm{~b}$ & $0.00 \mathrm{~b}$ & $1.00 \mathrm{~b}$ \\
\hline & Untreated seed & $0.00 \mathrm{~b}$ & $1.00 \mathrm{~b}$ & $0.00 \mathrm{~b}$ & $1.00 \mathrm{~b}$ & $0.00 \mathrm{~b}$ & $1.00 \mathrm{~b}$ \\
\hline & Extract & & & & & & \\
\hline & A. vera & $2.50 \mathrm{~b}$ & $1.02 \mathrm{~b}$ & $0.00 \mathrm{~b}$ & $1.00 \mathrm{~b}$ & $2.50 \mathrm{~b}$ & $1.02 \mathrm{~b}$ \\
\hline & C. arabica & $0.00 \mathrm{~b}$ & $1.00 \mathrm{~b}$ & $0.00 \mathrm{~b}$ & $1.00 \mathrm{~b}$ & $0.00 \mathrm{~b}$ & $1.00 \mathrm{~b}$ \\
\hline & Y. schidigera & $0.00 \mathrm{~b}$ & $1.00 \mathrm{~b}$ & $0.00 \mathrm{~b}$ & $1.00 \mathrm{~b}$ & $0.00 \mathrm{~b}$ & $1.00 \mathrm{~b}$ \\
\hline & Mean & 12.08 & 1.20 & 13.33 & 1.26 & 10.42 & 1.13 \\
\hline & $F$ test & $* * *$ & $* * *$ & $* * *$ & $* * *$ & $* * *$ & $* * *$ \\
\hline \multirow[t]{10}{*}{ Moneymaker } & Control & & & & & & \\
\hline & Sterile distilled water & $65.00 \mathrm{a}$ & $2.28 \mathrm{a}$ & $67.50 \mathrm{a}$ & $2.40 \mathrm{a}$ & $72.50 \mathrm{a}$ & $2.00 \mathrm{a}$ \\
\hline & Copper sulphate & $0.00 \mathrm{~b}$ & $1.00 \mathrm{~b}$ & $0.00 \mathrm{~b}$ & $1.00 \mathrm{~b}$ & $0.00 \mathrm{~b}$ & $1.00 \mathrm{~b}$ \\
\hline & Untreated seed & $0.00 \mathrm{~b}$ & $1.00 \mathrm{~b}$ & $0.00 \mathrm{~b}$ & $1.00 \mathrm{~b}$ & $0.00 \mathrm{~b}$ & $1.00 \mathrm{~b}$ \\
\hline & Plant extract & & & & & & \\
\hline & A. vera & $0.00 \mathrm{~b}$ & $1.00 \mathrm{~b}$ & $0.00 \mathrm{~b}$ & $1.00 \mathrm{~b}$ & $2.50 \mathrm{~b}$ & $1.02 \mathrm{~b}$ \\
\hline & C. arabica & $2.50 \mathrm{~b}$ & $1.02 \mathrm{~b}$ & $0.00 \mathrm{~b}$ & $1.00 \mathrm{~b}$ & $0.00 \mathrm{~b}$ & $1.00 \mathrm{~b}$ \\
\hline & Y. schidigera & $0.00 \mathrm{~b}$ & $1.00 \mathrm{~b}$ & $2.50 \mathrm{~b}$ & $1.02 \mathrm{~b}$ & $0.00 \mathrm{~b}$ & $1.00 \mathrm{~b}$ \\
\hline & Mean & 11.25 & 1.22 & 11.67 & 1.23 & 12.50 & 1.17 \\
\hline & $F$ test & $* * *$ & *** & $* * *$ & $* * *$ & $* * *$ & $* * *$ \\
\hline
\end{tabular}

*** Significant at $P=0.01 \mathrm{~b}$

${ }^{\text {a }}$ Percentage of seedlings with bacterial leaf spot symptoms

${ }^{\mathrm{b}}$ Disease severity index based on Horsfall and Barrett (1945) scale of 1-6 with modifications: $1=$ no disease and $6=>50 \%$ of leaves with BLS symptoms. Means followed by the same letters in a column are not significantly different based on SNK test at $P=0.05$

pyogenes has been documented (Ferro et al. 2003). Extracts from A. vera also affect several Gram-positive and negative bacteria (Cock 2008). The antibacterial activity of extracts from A. vera was reported to be due to a direct effect on the bacterial cells caused by the presence of anthraquinones (Boateng 2000) and saponin (Reynolds and Dweck 1999; Urch 1999). Other indirect effects have been reported to be associated with the presence of polysaccharides, which stimulate plant defence responses that destroy bacteria (Lawless and Allan 2000; Pugh et al. 2001). Murthy and Manonmani (2009) reported that plant extracts from processed coffee inhibited growth of food-borne pathogens such as Escherichia coli, Yersinia and Listeria species. The antibacterial activity of coffee is associated with substances produced by the roasting process such as millard products, carbohydrate caramelization and thermal composition products (Daglia et al. 1994). In addition, Glycyrrhiza species contain $\alpha$-glycyrrhetinic acid and glycyrrhizin, which inhibit DNA replication and RNA and protein synthesis of microbes (Kim et al. 2002). Other Glycyrrhiza species, e.g. G. glabra, inhibit growth of some Gram-negative bacteria such as Salmonella spp., Shigella spp. and E. coli (Shirazi 
et al. 2007). Extracts from $Y$. schidigera also have antibacterial activity, which was attributed to the presence of saponin, a compound found to inhibit microbial growth through hemolytic activity (Hassan et al. 2010). In the present study, observations of cell suspensions of $X$. perforans treated with extracts from $Y$. schidigera at $10 \%$ concentration using confocal microscopy revealed permeabilization of bacterial cells (data not shown).

In addition to reducing BLS in tomato seedlings, plant extracts from A. vera, C. arabica and Y. schidigera significantly improved germination $(P<0.05)$ of tomato seedlings (Table 3 ). At the same time, the vigor and dry mass of tomato seedlings were not affected by the treatment of seeds with plant extracts from A. vera, C. arabica, $G$. uralensis and $Y$. schidigera, indicating that these extracts were not phytotoxic to tomato seeds and seedling development. Other seed treatments with natural compounds of plant origin to control plant pathogens have been reported to have no negative effects on plant growth, seed viability or food quality (Opara and Wokocha 2008). Based on data from the present study, extracts from A. vera, $C$. arabica and $Y$. schidigera were the most promising plant extracts against BLS and can therefore be used to treat tomato seed. Additionally, they fulfilled the requirements for bioactive chemicals (Hewett and Griffiths 1986) and have the advantages of low mammalian toxicity, minimal health hazards and the least environmental pollution (Amadioha 2003; Singh 1994).

Under screenhouse conditions in Tanzania, using three tomato cultivars, transplants obtained from seed treated with extracts from A. vera, C. arabica and Y. schidigera had significantly lower BLS incidence and severity than tomato seedlings from seed treated with sterile distilled water (Table 4). The ability of these plant extracts to control BLS in the three tomato cultivars grown in Tanzania without negatively affecting seedling growth indicated the potential of using these plant extracts as seed treatment against BLS pathogens.

We also demonstrated that aqueous extracts of 13 plant species ( $15.5 \%$ of the tested extracts) had antimicrobial properties and inhibited the growth of $X$. perforans in in vitro and in planta assays. Plant extracts from A. vera, $C$. arabica and $Y$. schidigera were of particular interest as a control strategy to BLS of tomato because they consistently inhibited $X$. perforans in different experiments without negative effects on tomato seeds and seedlings. The ability of these plant extracts to control BLS xanthomonads in tomato also provides an alternative control approach against copper-resistant strains reported to be present in Tanzania (Shenge et al. 2007). These plants extracts must also be tested against BLS under farmers' conditions before they can be recommended for production of BLS free tomato transplants. More research is also needed to identify bioactive fractions from these plant extracts as well as their mechanisms of action.

Acknowledgments The authors wish to thank the Danish International Development Assistance (DANIDA) through ENRECA LIFE project No. 731 for providing funds for this work.

Open Access This article is distributed under the terms of the Creative Commons Attribution License which permits any use, distribution, and reproduction in any medium, provided the original author(s) and the source are credited.

\section{References}

Abdul-Baki AA, Anderson JD (1973) Vigor determination in soybean seed by multiple criteria. Crop Sci 13:630-633

Amadioha AC (2003) Evaluation of some plant leaf extracts against Colletotrichum lindemuthianum in cowpea. Acta Phytopathol Enthomol Hung 38:259-265

Anonymous (2006) List of new names and new combinations previously effectively, but not validly, published. Int J Syst Evol Microbiol 56:925-927

Black R, Seal S, Abubakar Z, Nono-Womdim R, Swai I (2001) Bacterial spot (Xanthomonas campestris pv. vesicatoria) of tomato and sweet pepper in Tanzania. Plant Pathol 50:810 (abstract)

Boateng JS (2000) Analysis of commercial samples of aloe. Ph.D. thesis, University of Strathclyde, Glasgow

Carrillo-Fasio JA, Garcia-Estrada RS, Allende-Molar R, MarquezZequera I, Millan- Ocampo S, Gaxiola-Espinoza G et al (2001) Sensitivity of Xanthomonas campestris pv. vesicatoria (Doidge) dye strains to copper. Rev Mex Fitopatol 19:72-77

Cock IE (2008) Antimicrobial activity of Aloe barbadensis Miller leaf gel components. Internet J Microbiol 4(2). http://www98.griffith. edu.au/dspace/bitstream/10072/21381/1/50582_1.pdf. Cited 12 April 2011

Daglia M, Cuzzoni MT, Dacarro C (1994) Antibacterial activity of coffee. J Agric Food Chem 42:2270-2272

Ferro VA, Bradbury F, Cameron P, Shakir E, Rahman SR, Stimson WH (2003) In vitro susceptibilities of Shigella flexneri and Streptococcus pyogenes to inner gel of Aloe barbadensis Miller. Antimicrob Agents Chemother 147:1137-1139

Gitaitis R, McCarter S, Jones J (1992) Disease control in tomato transplants produced in Georgia and Florida. Plant Dis 76:651656

Gore JP, O'Garro LW (1999) Xanthomonas campestris pv. vesicatoria from bell pepper and tomato in Barbados undergoes changes in race structure, virulence and sensitivity to chemical control agents. J Phytopathol 47:397-402

Hassan SM, Byrd JA, Cartwright AL, Bailey CA (2010) Hemolytic and antimicrobial activities differ among saponin-rich extracts from guar, quillaja, yucca, and soybean. Appl Biochem Biotechnol 162:1008-1017

Hewett PD, Griffiths DC (1986) Biology of seed treatment. In: Jeffs KA (ed) Seed treatments. BCPC Publications, Thornton Health, Surrey, pp 7-12

Horsfall JG, Barrett RW (1945) An improved grading system for measuring plant disease. Phytopathology 35:655 (abstract)

International Seed Federation (ISF) (2007) Method for the detection of Xanthomonas campestris pv. vesicatoria on tomato seed. ISF Secretariat, Chemin du Reposoir, Nyon

International Seed Testing Association (ISTA) (2005) International rules for seed testing. Bassersdorf 
Jones JB, Bouzar H, Stall RE, Almira EC, Roberts PD, Bowen BW, Sudberry J, Strickler PM, Chun J (2000) Systematic analysis of xanthomonads (Xanthomonas spp.) associated with pepper and tomato lesions. Int J Syst Evol Microbiol 50:1211-1219

Jones JB, Lacy GH, Bouzar H, Stall RE, Schaad NW (2004) Reclassification of the xanthomonads associated with bacterial spot disease of tomato and pepper. Syst Appl Microbiol 27:755762

Kaaya NKF, Mortensen CN, Mabagala RB, Massomo SMS (2003) A guide on seed-borne bacterial diseases of tomato in Tanzania. Technical Bulletin, Danish Government Institute of Seed Pathology for Developing Countries (DGISP), Copenhagen, Denmark

Kim HK, Park Y, Kim HN, Choi BH, Jeong HG, Lee DG, Hahm KS (2002) Antimicrobial mechanism of $\beta$-glycyrrhetinic acid isolated from licorice, Glycyrrhiza glabra. Biotechnol Lett 24:18991902

Kumar J, Parmar BS (1996) Physicochemical and chemical variation in neem oils and some bioactivity leads against Spodoptera litura F. J Agric Food Chem 44:2137-2143

Lawless J, Allan J (2000) The chemical composition of Aloe vera. In: Aloe vera natural wonder cure. Thorsons Publishing, London, pp 161-171

Lee SD, Cho YS (1996) Copper resistance and race distribution of Xanthomonas campestris pv. vesicatoria on pepper in Korea. Korean J Plant Pathol 12:150-155

Martin HL, Hamilton VA, Kopittke RA (2004) Copper tolerance in Australian populations of Xanthomonas campestris pv. vesicatoria contributes to poor field control of bacterial spot of pepper. Plant Dis 88:921-924

Murthy PS, Manonmani HK (2009) Physico-chemical, antioxidant and antimicrobial properties of Indian monsooned coffee. Eur Food Res Technol 229:645-650

Myung IS, Jeong IH, Moon SY, Lee SW, Shim HS (2010) A new disease, arboricola leaf spot of bell pepper, caused by Xanthomonas arboricola. Plant Dis 94:271(abstract)

Opara EU, Wokocha RC (2008) Efficacy of some plant extracts on the in vitro and in vivo control of Xanthomonas campestris pv. vesicatoria. Agric J 3:163-170

Prakash A, Rao J (1997) Botanical pesticides in agriculture. Lewis Publishers, London
Pugh N, Ross SA, ElSohly MA, Pasco DS (2001) Characterization of aloeride, a new high-molecular-weight polysaccharide from Aloe vera with potent immunostimulatory activity. J Agric Food Chem 49:1030-1034

Punina NV, Ignatov AN, Pekhtereva ESH, Kornev KP, Matveeva EV, Polityko VA, Budenkov NI, Schaad NW (2009) Occurrence of Xanthomonas campestris pv. raphani on tomato plants in the Russian Federation. Acta Hortic 808:287-290

Reynolds T, Dweck AC (1999) Aloe vera leaf gel: a review update. J Ethnopharmacol 68:3-37

Scheck HJ, Pscheidt JW, Moore LW (1996) Copper and streptomycin resistance in strains of Pseudomonas syringae from Pacific Northwest nurseries. Plant Dis 80:1034-1039

Shenge KC (2006) Bacterial speck and spot diseases of tomato in Tanzania: pathogen characterization, epidemiology and management options. PhD thesis, Sokoine University of Agriculture, Morogoro

Shenge KC, Mabagala RB, Mortensen CN (2007) Identification and characterization of strains of Xanthomonas campestris pv. vesicatoria from Tanzania by biolog system and sensitivity to antibiotics. Afric J Biotech 6:015-022

Shirazi MH, Ranjbar R, Eshraghi S, Sadeghi G, Jonaidi N, Bazzaz N, Izadi M, Sadeghifard N (2007) An evaluation of antibacterial activity of Glycyrrhiza glabra extract on the growth of Salmonella, Shigella and ETEC E. coli. J Biol Sci 7:827-829

Singh DC (1994) Scope of medicinal and aromatic plants in pest management. In: Narwal SS, Tauro P (eds) International symposium, allelopathy in sustainable agriculture, forestry and environment, New Delhi, p 68

Stall RE, Beaulieu C, Egel D, Hodge NC, Leite RP, Minsavage GV, Bouzar H, Jones JB, Alvarez AM, Benedict AA (1994) Two genetically diverse groups of strains are included in Xanthomonas campestris pv. vesicatoria. Int J Syt Bacteriol 44:47-53

Tamir-Ariel D, Navon N, Burdman S (2007) Identification of genes in Xanthomonas campestris pv. vesicatoria induced during its interaction with tomato. J Bacteriol 189:6359-6371

Urch D (1999) Aloe vera nature's gift. Blackdown Publications, Bristol 